\title{
Treatment Outcome and its Predictors Among Diabetic Patients Attending at Selected Hospitals of Southern Ethiopia.
}

Bereket Beyene ( $\sim$ bereket2007beyene@gmail.com )

Hawassa University College of Medicine and Health Sciences

Dawit Hoyiso

Hawassa University College of Medicine and Health Sciences

Kinfu Woldu

Hawassa University College of Medicine and Health Sciences

\section{Research}

Keywords: Magnitude, treatment outcome, predictors.

Posted Date: October 1st, 2021

DOl: https://doi.org/10.21203/rs.3.rs-917406/v1

License: (1) (i) This work is licensed under a Creative Commons Attribution 4.0 International License. Read Full License 


\section{Abstract}

Background: Diabetes is one of the largest health emergencies of the 21 st century. The World Health Organization (WHO) estimates that globally, hyperglycaemia is the third highest risk factor for premature mortality, after high blood pressure and tobacco use. It is an important cause of blindness, kidney failure, lower limb amputation and other long-term consequences that impact significantly on quality of life. It result peoples in a disease, death and increase a health care expenditure.

Objectives: To determine treatment outcome of Diabetes mellitus and its predictors among patients attending diabetes treatments at selected hospitals of southern Ethiopia, 2021.

Methods: All diabetic patients who attended selected hospitals of southern Ethiopia were a source population. Institution based cross-sectional study design was conducted at selected hospitals of southern Ethiopia. Patient's data was collected using pretested questionnaire. After cleaning and checking for errors, the data was entered in to Epi-data to minimize error then exported to SPSS for analysis. Descriptive findings were presented by tables and charts. The outcome variable was analyzed by using logistic regression model to identify predictors after assumptions of regression analysis had checked. All the independent variables with $p<0.25$ was used as a candidate for multivariate analysis. Then the level of significance will be set at $p<0.05$ and AOR with $95 \%$ CL was done as the final model.

Result: From the total sample; 277 (65.6\%) were found to be good treatment outcome. The number of medication taken AOR 95\% Cl; $0.924(0.869,0.983)$, presence of complication AOR 95\% Cl; $0.425(0.217$, $.832)$, increased fasting blood glucose AOR $95 \% \mathrm{Cl} ; 0.080(0.034,0.188)$ were found to be independent predictors. Since the magnitude of treatment outcome found to be low, provision of health information about the adhering to prescribed medication and monitoring fasting blood glucose level will bring good clinical outcome.

\section{Introduction}

Diabetes mellitus is not a single disease entity but rather a group of metabolic disorders sharing the common underlying feature of hyperglycaemia, which results from defects in insulin secretion, insulin action, or both(1). According to the 2015 report of IDF, about 415 million people worldwide, or $8.8 \%$ of adults aged 20-79 years, were estimated to have DM. Of these, about $75 \%$ lived in low- and middle-income countries. If these trends continue, by 2040 , some 642 million people (or one in ten adults) will have DM. The largest increases will take place in the regions where economies are moving from low-income to middle-income levels. In 2015, the IDF also estimated that, in the Africa region, 14.2 million adults aged 2079 years had diabetes, representing a prevalence of $3.2 \%$ (2). Poor diabetes outcome lead to complications in many parts of the body and can increase the overall risk of dying prematurely. Possible complications include heart attack, stroke, kidney failure, leg amputation, vision loss and nerve damage. In pregnancy, poorly controlled diabetes increases the risk of fetal death and other complications (3). The World Health Organization (WHO) estimates that globally, hyperglycaemia is the third highest risk factor for premature mortality, after high blood pressure and tobacco use (4). It result peoples in a disease, death and increase a 
health care expenditure (5). It is the leading cause of end-stage renal disease (ESRD), traumatic lower extremity amputations, and adult blindness. It also predisposes to cardiovascular diseases. With an increasing incidence worldwide, DM will be a leading cause of morbidity and mortality in the future. The goal of treatment for DM is to prevent mortality and complications by normalizing blood glucose level. But blood glucose level might be increased despite appropriate therapy resulting in complications, such as disturbances in fat metabolism, nerve damage, and eye disease $(4,6)$. Diabetes is a major cause of blindness, kidney failure, heart attacks, stroke and lower limb amputation (7).

Ethiopia is among the top four countries with the highest adult diabetic populations in sub-Saharan Africa. In Ethiopia According to IDF 2017 Country report the total country prevalence of diabetes mellitus was 5.2\%, Number of people with diabetes was 2,567,900, Number of people with undiagnosed diabetes was 1 , 960300 , Number of deaths due to diabetes was 31,000 which accounts $81.8 \%$ of deaths due to diabetes in people under 60 years. Patient attendance rates and medical admissions related to diabetes in major hospitals have been rising. In Addis Ababa Ethiopia diabetes-related admissions in have increased from 7\% in 2005 to $34 \%$ in 2009 (8). This requires a shift in healthcare priorities and up-to- date data on treatment outcome and it's predictors in Ethiopia. The consequences of diabetes due to poor control of sugar in Ethiopia ranges from acute complication like DKA, chronic complication and death.

However, there no research evidences in the study area showing treatment outcomes and predictors. So, the aim of this study is to assess treatment outcome and its predictors in the study area in which it provides input for health care providers and institution.

\section{Objectives}

\section{General objective}

To assess treatment outcome and its predictors among DM patients attending treatments at selected hospitals of Southern Ethiopia, 2021

\section{Specific Objective}

To identify treatment outcome of DM patients attending at selected hospitals of southern Ethiopia, 2021

To identify predictors of treatment outcome among DM patients attending treatments at selected hospitals of southern Ethiopia, 2021

\section{Methods And Materials}

\section{Study area and period:}

\section{Study area:}

The study was conducted at 3 selected hospitals called Hawassa university comprehensive specialized hospital, Wolaita Sodo University Teaching Referral Hospital and Nigist ellen general hospital. Hawassa 
University Comprehensive Specialized Hospital is a teaching Hospital located $275 \mathrm{~km}$ south of Addis Ababa, in Hawassa town Sidama region. Nigist Ellen Mohammed Memorial hospital is the General hospital found in Hadiya Zone, which is 230 kilometer from Addis Ababa. Wolaita Sodo University Teaching Referral Hospital is also found in Sodo town which is $328 \mathrm{~km}$ from Addis Ababa

Study period: The study was conducted from October 24, 2021- February, 30, 2021

\section{Study design}

Institution based cross sectional study design had been conducted at selected hospitals of southern Ethiopia.

Source population: All diabetic patients who attended selected hospitals of southern Ethiopia during study period.

Study population: All sampled DM patients who attended outpatient department at selected hospitals of southern Ethiopia during the study period

\section{Inclusion and exclusion criteria}

All diabetic patients who attended outpatient department at selected hospitals in southern Ethiopia who can give informed consent will be included. Whereas, those who are not volunteer have been excluded

\section{Sample size}

Sample size calculation is based on the single population proportion formula.

$\mathbf{N}=\left[(Z a / 2)^{2} P(1-P)\right] / d^{2}$ is used.

$\mathrm{N}=$ is sample size,

$\mathrm{Za} / 2$ is $Z$ value which is 1.96 at $95 \%$ confidence interval,

$\mathrm{P}$ is proportion of diabetic patients and is taken 0.5 and $\mathrm{d}$ is marginal error which is 0.05 .

At $95 \%$ confidence interval and by taking $p$ value of 0.5 just to maximize the sample size; in order to accommodate the maximum variety of patients coming to the diabetic clinics, the sample size will be 384 . Adding $10 \%$ non-respondent rate, the final sample size will be 422 .

\section{Sampling Technique}

The study area was selected randomly using lottery method from those hospitals found in southern region of Ethiopia. Proportionate sample allocation was done to allocate samples for each hospital of Adare general hospital, Nigist Ellen general hospital and Wolayta sodo general hospital. So, every patient having appointment during study period was selected since patients visiting the health institutions are random in 
nature till the maximum number of sample size will be achieved. So, exit interview was conducted at each hospital.

\section{Variables}

\section{Dependent Variable}

Treatment outcome

\section{Independent Variables}

Socio demographic variables: - Age, Sex, educational status, marital status, income and job status.

Behavioral Variables are: - Alcohol drinking, cigarette smoking, Khat chewing, Physical activity practice, practices to prescribed diet regimen.

Disease and medication related Variables are: - Duration of Diabetes, Type of treatment, co-morbid illness, Fasting blood glucose level, DM control, Medication adherence

\section{Data collection Instrument}

In order to collect data from the patient, Data abstraction sheets, structured questionnaire and observation checklist was used. Data abstraction sheets were developed by investigator by reviewing different literature to collect relevant information from patient charts and laboratory results. Structured questionnaire for face to face interview was used to obtain patient Adherence level will be classified by taking the sum of 8 question responses and grouped as high, medium or low, if the total score will be $\geq 31$ to 2 and 0 , greater respectively using Morisky medication scale. The questionnaires have 6 parts, including sociodemographic information, Patient's Physical activity questions, the Morisky medication adherence Scale with 8 items (MMAS-8) and laboratory and medication related variables. The data have been collected by 11 BSc Nurses and 3 M.Sc. health professionals had supervised data collection process. At the end the outcome will be measured which may be good or poor treatment outcome

\section{Data processing and analysis}

After checking collected data visually for completeness, the responses was cleaned, edited, coded and entered into the computer using Epi-data version 3.1. The data will be then exported to SPSS version 20.0. The data will be checked for missed value before analysis. The descriptive analysis including frequency will be used to assess frequency of variables with independent variables. Binary logistic regression will be carried out to assess the association of treatment outcome of DM with independent variables to determine predictors of treatment outcome having odds ratios with $95 \%$ confidence interval. Finally forward stepwise logistic regression model with all independent variables having $\mathrm{p}$ value $<0.25$ will be fitted and adjusted odds ratio will be calculated to identify independent predictors of treatment outcome of DM.

\section{Data Quality}


To assure quality of the data, properly designed data collection tool was prepared, pretested in hospital which would not be selected to check for understandability and applicability of the instrument and 3 day training will be given to data collectors and supervisor. Besides, on each data collection day, the collected data was reviewed and checked for its completeness by supervisor and principal investigator. Then data was checked and entered into Epi-data version 3.1 for double data entry verification.

\section{Ethical Considerations}

In order to follow the ethical and legal standards of scientific investigation, the study was conducted after approval of the proposal by Ethical Review Committee of Hawassa University. Permission for conduct of study was obtained from authorities at selected hospitals. Written informed consent was obtained from each study participant by assuring privacy and confidentiality throughout the data collection period in the Hospital. Individuals who were unwilling to participate from the beginning or at any part of the interview were allowed to withdraw. There was no risk or hazardous procedures putting the participants at harm.

\section{Results}

\section{Socio demographic characteristic of the respondents}

Out of total 422 sampled diabetes patients; yield a response rate of $100 \%$. Among them $276(62.3 \%)$ and $310(70 \%)$ were male and married respectively. The mean age for the participants was 46.51 with SD of 13.85. (See table 1below).

Table 1. Socio demographic characteristics and factors associated with medication adherence for the respondents at selected hospitals of southern Ethiopia, $2021(n=422)$ 


\begin{tabular}{|c|c|c|c|c|}
\hline S.N & Sociodemographic variables & Categories & Frequency & Percent \\
\hline \multirow[t]{3}{*}{1} & \multirow[t]{3}{*}{ Age } & young age gruop & 140 & 33.2 \\
\hline & & middle age gruop & 139 & 32.9 \\
\hline & & old age gruop & 143 & 33.9 \\
\hline \multirow[t]{2}{*}{1} & \multirow[t]{2}{*}{ Sex } & male & 264 & 62.6 \\
\hline & & female & 158 & 37.4 \\
\hline \multirow[t]{2}{*}{2} & \multirow[t]{2}{*}{ Address } & urban & 277 & 65.6 \\
\hline & & rural & 145 & 34.4 \\
\hline \multirow[t]{2}{*}{3} & \multirow[t]{2}{*}{ Region } & SNNPR & 326 & 77.3 \\
\hline & & Sidama & 96 & 22.8 \\
\hline \multirow[t]{3}{*}{4} & \multirow[t]{3}{*}{ Marital status } & single & 82 & 19.4 \\
\hline & & married & 304 & 72.0 \\
\hline & & Widow/divorced & 36 & 8.5 \\
\hline \multirow[t]{5}{*}{5} & \multirow[t]{5}{*}{ Religion } & protestant & 264 & 62.6 \\
\hline & & orthodox & 104 & 24.6 \\
\hline & & catholic & 4 & 0.9 \\
\hline & & muslim & 46 & 10.9 \\
\hline & & others & 4 & 0.9 \\
\hline \multirow[t]{5}{*}{7} & \multirow[t]{5}{*}{ Educational status } & illitrate & 40 & 9.5 \\
\hline & & readandwrite & 49 & 11.6 \\
\hline & & grade1-8 & 113 & 26.8 \\
\hline & & grade $10-12$ & 97 & 23.0 \\
\hline & & College above & 123 & 29.1 \\
\hline \multirow[t]{7}{*}{8} & \multirow[t]{7}{*}{ Occupational status } & Un employeed & 11 & 2.6 \\
\hline & & retired & 45 & 10.7 \\
\hline & & students & 32 & 7.6 \\
\hline & & disabled & 1 & .2 \\
\hline & & housewife & 79 & 18.7 \\
\hline & & marchant & 45 & 10.7 \\
\hline & & $\begin{array}{l}\text { Daily labourer } \\
\text { Page } 7 / 16\end{array}$ & 4 & .9 \\
\hline
\end{tabular}




\begin{tabular}{|llll|}
\hline farmer & 68 & 16.1 \\
\hline Government employeed & 95 & 22.5 \\
\hline Private employeed & 9 & 2.1 \\
\hline others & 33 & 7.8 \\
\hline Income & low income group & 136 & 32.2 \\
\hline middle income group & 145 & 34.4 \\
\hline high income gruop & 141 & 33.4 \\
\hline
\end{tabular}

\section{Behavioural characteristics and factors}

From the respondents; those participants who didn't drink alcohol and smoke cigarate were $95.7 \%$ and 98.1 $\%$ respectively. ( see table 2 below).

Table 2. Behavioural related characteristics for the respondents at selected hospitals of southern Ethiopia, $2021(n=422)$.

\begin{tabular}{|lllll|}
\hline S. N & Behavioural factors & Categories & frequency & percent \\
\hline 1 & Dietary practice & poor practice & 180 & 42.7 \\
\cline { 3 - 5 } & & good practice & 242 & 57.3 \\
\hline 2 & Physical activity & Inactive( poor) & 258 & 61.1 \\
\cline { 3 - 5 } & & Active ( good) & 164 & 38.9 \\
\hline 3 & Alcohol drinking & yes & 18 & 4.3 \\
\cline { 3 - 5 } & & no & 404 & 95.7 \\
\hline \multirow{2}{*}{4} & \multirow{2}{*}{ Smoke cigarette } & yes & 8 & 1.9 \\
\cline { 3 - 5 } & & no & 414 & 98.1 \\
\cline { 3 - 5 } & & & & \\
\hline
\end{tabular}

\section{Disease and medication related characteristics}

In this study 365 (82.4\%) were type II diabetes and 277 (62.5\%) had developed complication. Regard to medication adherence and treatment outcome; 195 (44\%) and $290(65.5 \%)$ were found to be poor and good adherence and outcome respectively. (See table 3 below)

Table 3. Disease and medication related characteristics for the respondents at selected hospitals of southern Ethiopia, 2021 ( $n=422)$. 


\begin{tabular}{|c|c|c|c|c|}
\hline & Disease and medication related factors & Categories & frequency & percent \\
\hline \multirow{2}{*}{1.} & \multirow[t]{2}{*}{ Past hx of admission due to DM } & yes & 284 & 64.1 \\
\hline & & no & 159 & 35.9 \\
\hline \multirow[t]{2}{*}{2} & \multirow[t]{2}{*}{ Presence of complication } & yes & 267 & 63.3 \\
\hline & & no & 155 & 36.7 \\
\hline \multirow[t]{4}{*}{3} & \multirow[t]{4}{*}{ Type of complication } & DKA & 195 & 46.2 \\
\hline & & hhnks & 21 & 5.0 \\
\hline & & others & 44 & 10.4 \\
\hline & & hypoglycemia & 7 & 1.7 \\
\hline \multirow[t]{3}{*}{4} & \multirow[t]{3}{*}{ Type of DM } & type1 & 143 & 33.9 \\
\hline & & type2 & 272 & 64.5 \\
\hline & & others & 7 & 1.7 \\
\hline \multirow[t]{2}{*}{5} & \multirow[t]{2}{*}{ MAT (Medication Adherence) } & not adhered & 16 & 3.8 \\
\hline & & adhered & 406 & 96.2 \\
\hline \multirow[t]{2}{*}{6} & \multirow[t]{2}{*}{ RX 3(current DM medication intake) } & insulin & 175 & 41.5 \\
\hline & & Oral & 247 & 58.5 \\
\hline \multirow[t]{2}{*}{9} & \multirow[t]{2}{*}{ Blood glucose level } & $\begin{array}{l}\text { FBS between 60- } \\
140\end{array}$ & 132 & 31.3 \\
\hline & & FBS $>=140$ & 290 & 68.7 \\
\hline \multirow[t]{5}{*}{10} & \multirow{5}{*}{$\begin{array}{l}\text { Frequency of Blood glucose Level } \\
\text { measurement }\end{array}$} & never & 29 & 6.9 \\
\hline & & once & 31 & 7.3 \\
\hline & & sometimes & 167 & 39.6 \\
\hline & & mostly & 99 & 23.5 \\
\hline & & always & 96 & 22.7 \\
\hline
\end{tabular}

\section{Prevalence of treatment outcome}

From the total sample the treatment outcome 277 (65.6\%) were good. Whereas 145 (34.4\%) were found to be poor. 
From the sociodemographic variables affecting the respondents; only marital status and educational status were found to be associated significantly with the treatment outcome. (See table 4 below).

Table 4:- Sociodemographic factors associated with treatment outcome among_the respondents at selected hospitals of southern Ethiopia, 2021 ( $n=422)$.

\begin{tabular}{|c|c|c|c|c|c|c|c|c|}
\hline \multirow[t]{2}{*}{ S.n } & \multirow[t]{2}{*}{ Variables } & \multirow[t]{2}{*}{ category } & \multicolumn{2}{|c|}{ Glycemic control } & \multirow[t]{2}{*}{$\operatorname{Exp}(B)$} & \multicolumn{2}{|c|}{$\begin{array}{l}\text { 95\% C.I.for } \\
\text { EXP(B) }\end{array}$} & \multirow[t]{2}{*}{$\begin{array}{l}\mathrm{p}- \\
\text { value }\end{array}$} \\
\hline & & & Good & poor & & Lower & Upper & \\
\hline \multirow[t]{3}{*}{1} & \multirow[t]{3}{*}{ Age } & young & $88(31.8)$ & $52(35.9)$ & & & & \multirow[t]{3}{*}{0.511} \\
\hline & & middle & $90(32.5)$ & 49(33.8) & 0.921 & 0.565 & 1.502 & \\
\hline & & old & $99(35.7)$ & $44(30.3)$ & 0.752 & 0.459 & 1.232 & \\
\hline \multirow[t]{2}{*}{2} & Sex & male & $172(62.1)$ & $92(63.4)$ & 1.060 & 0.699 & 1.607 & \multirow[t]{2}{*}{0.78} \\
\hline & & Female & 105(37.9) & $53(36.6)$ & & & & \\
\hline \multirow[t]{2}{*}{3} & \multirow[t]{2}{*}{ address } & Urban & $190(68.6)$ & $87(60.0)$ & 0.687 & 0.452 & 1.043 & \multirow[t]{2}{*}{0.078} \\
\hline & & Rural & 87(31.4) & $58(40.0)$ & & & & \\
\hline \multirow[t]{3}{*}{4} & \multirow{3}{*}{$\begin{array}{l}\text { Marital } \\
\text { status }\end{array}$} & single & $58(20.9)$ & $24(16.6)$ & 3.103 & .659 & 14.625 & \multirow[t]{3}{*}{0.033} \\
\hline & & married & 188(67.9) & 116(80.0) & 4.628 & 1.039 & 20.604 & \\
\hline & & Widow/divorced & $31(11.2)$ & $5(3.5)$ & 1.406 & .206 & 9.619 & \\
\hline \multirow[t]{5}{*}{5} & \multirow{5}{*}{$\begin{array}{l}\text { Educational } \\
\text { status }\end{array}$} & illitrate & $22(7.9)$ & $18(12.4)$ & 1.977 & .949 & 4.120 & \multirow[t]{4}{*}{0.04} \\
\hline & & Read and write & $39(14.1)$ & $10(6.9)$ & .620 & .280 & 1.373 & \\
\hline & & grade1-8 & $66(23.8)$ & $47(32.4)$ & 1.721 & 1.004 & 2.951 & \\
\hline & & grade10-12 & $63(22.7)$ & $34(23.4)$ & 1.304 & .738 & 2.306 & \\
\hline & & $\begin{array}{l}\text { College and } \\
\text { above }\end{array}$ & $87(31.4)$ & $36(24.8)$ & & & & 0.443 \\
\hline \multirow[t]{3}{*}{7} & \multirow[t]{3}{*}{ Income } & low & $69(28.2)$ & $31(22.0)$ & & & & \multirow[t]{3}{*}{0.355} \\
\hline & & middle & $87(35.5)$ & $58(41.1)$ & 0.769 & 0.446 & 1.326 & \\
\hline & & high & $89(36.3)$ & $52(36.9)$ & 1.141 & 0.708 & 1.838 & \\
\hline
\end{tabular}

\section{Behavioural factors affecting treatment outcome}

From the four behavioural variables included in the study; none of them were found to be associated significantly ( See table 5 below). 
Table 5:- behavioural factors associated with treatment outcome among the respondents at selected hospitals of southern Ethiopia, $2021(n=422)$.

\begin{tabular}{|c|c|c|c|c|c|c|c|c|}
\hline \multirow[t]{2}{*}{ S.n } & \multirow[t]{2}{*}{ Variables } & \multirow[t]{2}{*}{ category } & \multicolumn{2}{|c|}{ Glycemic control } & \multirow[t]{2}{*}{$\operatorname{Exp}(B)$} & \multicolumn{2}{|c|}{$\begin{array}{l}95 \% \text { C.I.for } \\
\text { EXP(B) }\end{array}$} & \multirow[t]{2}{*}{$\begin{array}{l}\mathrm{p}- \\
\text { value }\end{array}$} \\
\hline & & & Good & poor & & Lower & Upper & \\
\hline \multirow[t]{2}{*}{1} & Alcohol & yes & $11(4)$ & $7(4.8)$ & & & & \multirow[t]{2}{*}{0.68} \\
\hline & & No & $266(96)$ & 138(95.2) & 0.815 & 0.309 & 2.150 & \\
\hline \multirow[t]{2}{*}{2} & Smoking & yes & $3(1.1)$ & $5(3.4)$ & & & & \multirow[t]{2}{*}{0.10} \\
\hline & & No & 274(98.9) & 140(96.6) & 0.307 & 0.072 & 1.301 & \\
\hline \multirow[t]{2}{*}{3} & Dietary practice & poor & 112(40.4) & 68(46.9) & 1.317 & 0.877 & 1.97 & \multirow[t]{2}{*}{0.184} \\
\hline & & good & 165(59.6) & 77(53.1) & & & & \\
\hline \multirow[t]{2}{*}{4} & Physical activity & inactive & $173(62.5)$ & $85(58.6)$ & 0.852 & 0.565 & 1.284 & \multirow[t]{2}{*}{0.443} \\
\hline & & active & 104(37.5) & $60(41.4)$ & & & & \\
\hline
\end{tabular}

\section{Disease and medication related factors associated with treatment outcome}

From eight variables studied under disease and medication related factor ; the following four factors called Past history of admission, Type of complication, Blood glucose Check-up and Blood glucose level were found to be associated significantly (See table 6 below).

Table 6:- behavioural factors associated with treatment outcome among_the respondents at selected hospitals of southern Ethiopia, $2021(n=422)$. 


\begin{tabular}{|c|c|c|c|c|c|c|c|c|}
\hline \multirow[t]{2}{*}{ S.n } & \multirow[t]{2}{*}{ Variables } & \multirow[t]{2}{*}{ category } & \multicolumn{2}{|c|}{ Gycemic control } & \multirow[t]{2}{*}{$\operatorname{Exp}(B)$} & \multicolumn{3}{|c|}{$\begin{array}{l}\text { 95\% C.l.for } \\
\operatorname{EXP(B)}\end{array}$} \\
\hline & & & Good & poor & & Lower & Upper & \\
\hline \multirow[t]{2}{*}{1} & \multirow{2}{*}{$\begin{array}{l}\text { Past history } \\
\text { of admission }\end{array}$} & yes & 164(59.2) & 103(71.0) & 1.690 & 1.098 & 2.601 & \multirow[t]{2}{*}{0.017} \\
\hline & & No & & & & & & \\
\hline \multirow[t]{2}{*}{2} & \multirow{2}{*}{$\begin{array}{l}\text { Presence of } \\
\text { complication }\end{array}$} & yes & 176(63.5) & $91(62.8)$ & 0.967 & 0.638 & 1.466 & \multirow[t]{2}{*}{0.875} \\
\hline & & No & & & & & & \\
\hline \multirow[t]{2}{*}{3} & \multirow{2}{*}{$\begin{array}{l}\text { Type of } \\
\text { complication }\end{array}$} & DKA & 121(77.1) & $64(64.6)$ & 0.465 & 0.259 & 0.833 & \multirow[t]{2}{*}{0.035} \\
\hline & & hyperglycemia & 36 (22.9) & $35(35.4)$ & & & & \\
\hline \multirow[t]{3}{*}{4} & \multirow[t]{3}{*}{ Type of DM } & Type I & $90(32.5)$ & $53(36.6)$ & 1.472 & 0.276 & 7.857 & \multirow[t]{3}{*}{0.684} \\
\hline & & Type II & 182(65.7) & $90(62.1)$ & 1.236 & 0.235 & 6.496 & \\
\hline & & others & $5(1.8)$ & $2(1.4)$ & & & & \\
\hline \multirow[t]{2}{*}{5} & \multirow{2}{*}{$\begin{array}{l}\text { Medication } \\
\text { adherence }\end{array}$} & yes & 264(95.3) & 142(97.9) & & & & \multirow[t]{2}{*}{0.192} \\
\hline & & no & $13(4.7)$ & $3(2.1)$ & 2.331 & 0.653 & 8.315 & \\
\hline \multirow[t]{2}{*}{6} & \multirow{2}{*}{$\begin{array}{l}\text { Medication } \\
\text { intake }\end{array}$} & Insulin & $115(41.5)$ & $60(41.4)$ & & & & \multirow[t]{2}{*}{0.978} \\
\hline & & oral & $162(58.5)$ & $85(58.6)$ & 1.006 & 0.669 & 1.512 & \\
\hline \multirow[t]{5}{*}{7} & \multirow{5}{*}{$\begin{array}{l}\text { Blood } \\
\text { glucose } \\
\text { Check- up }\end{array}$} & never & $22(7.9)$ & $7(4.8)$ & 0.376 & 0.147 & 0.963 & \multirow[t]{5}{*}{0.031} \\
\hline & & once & 19(6.9) & $12(8.3)$ & 0.746 & 0.327 & 1.706 & \\
\hline & & sometimes & 121(43.7) & $46(31.7)$ & 0.449 & 0.266 & 0.760 & \\
\hline & & mostly & 63 (22.7) & $36(24.8)$ & 0.675 & 0.381 & 1.198 & \\
\hline & & always & 277(65.6) & $145(34.4)$ & & & & \\
\hline \multirow[t]{2}{*}{8} & \multirow[t]{2}{*}{$\begin{array}{l}\text { Blood } \\
\text { glucose level }\end{array}$} & $\begin{array}{l}\text { FBS Between } \\
60-140 \mathrm{mg} / \mathrm{dl}\end{array}$ & 118(42.6) & 14(9.7) & & & & \\
\hline & & $\begin{array}{l}\text { FBS >= } \\
140 \mathrm{mg} / \mathrm{dl}\end{array}$ & 159(57.4) & 131(90.3) & 0.144 & 0.079 & 0.262 & .000 \\
\hline
\end{tabular}

From the total of 19 variables studied under this study; only dietary practice, presence of complication and having FBS >= 140 were found to be independently associated with treatment outcome (See table 7).

Table 7. Independent predictors predicting treatment outcome among_the respondents at selected hospitals of southern Ethiopia, $2021(n=422)$. 


\begin{tabular}{|c|c|c|c|c|c|c|c|}
\hline \multirow[t]{2}{*}{ Variables } & \multirow[t]{2}{*}{ Category } & \multicolumn{3}{|c|}{ COR :95\% C.I. for } & \multicolumn{3}{|c|}{ AOR 95\% C.I. for } \\
\hline & & $\operatorname{EXP}(B)$ & Lower & Upper & $\operatorname{EXP}(B)$ & Lower & Upper \\
\hline \multirow[t]{2}{*}{ Dietary practice } & Good & 1.317 & 0.877 & 1.97 & 0.924 & 0.869 & 0.983 \\
\hline & Poor & & & & & & \\
\hline \multirow{2}{*}{$\begin{array}{l}\text { Presence of } \\
\text { complication }\end{array}$} & yes & & & & & & \\
\hline & No & 0.967 & 0.638 & 1.466 & 0.425 & 0.217 & .832 \\
\hline \multirow[t]{2}{*}{ FBS } & $60-140 \mathrm{mg} / \mathrm{dl}$ & & & & & & \\
\hline & $\begin{array}{l}>=140 \\
\mathrm{mg} / \mathrm{dl}\end{array}$ & 0.144 & 0.079 & 0.262 & 0.080 & 0.034 & 0.188 \\
\hline
\end{tabular}

\section{Discussion}

According to this study from the total sample size of 422 participants; 277 (65.6\%) were found to be good treatment outcome; Whereas 145 (34.4\%) were found to be poor treatment outcome. But it is lower than different studies done in debretabor in Ethiopia, (71.4\%) (8); Dessie Referral Hospital (70.8\%) (9); Jimma University Teaching Hospital (70.9\%) (10). This might be due to difference in measurement scale, improved patient treatment outcome and studies done in different health setting in southern Ethiopia.

This study also showed that those participants who do not adhered to the recommended dietary practice had $7.6 \%$ times AOR; $0.924 ; 95 \%(0.869,0.983)$ more developed poor treatment outcome compared to those who adhered to dietary practice. So, this study revealed that adherence to dietary recommendation had significant associated with glycemic control among diabetes patients. This study result is consistent with the study done in Gulf Cooperation Council Countries (11) and turkey (12) demonstrated that poor compliance to diet control is significantly associated with poor glycemic control. It is also found to be associated independently according to the study done in debretabor in Ethiopia (8).

It is obvious that lifestyle modifications, such as compliance to the recommended diet, are very important strategies for controlling patients' blood sugar. Thus, poor adherence to a recommended diet might make it more difficult to control blood sugar.

This study also showed that those participants who have complication were found to be $57.5 \%$ times AOR; $0.425 ; 95 \%(0.217,0.832)$ develop poor treatment outcome when compared with that of who had not complication.

Other studies done in south west tertiary hospitals (14) and Gondar hospital (13) in Ethiopia respectively indicated that having complication were strongly associated with poor glycaemic outcome. Other studies at mult selected public hospitals of western Ethiopia (14) also revealed that there is strong association of presence of complication with poor glycemic control. 
This study also indicated that those participants who had FBS $>=140 \mathrm{mg} / \mathrm{dl}$ were found to be $8 \%$ times AOR; $0.080 ; 95 \%(0.034,0.188)$ times developed poor treatment outcome when compared with that of who had FBS between 60 and $140 \mathrm{mg} / \mathrm{dl}$. It is generally accepted truth that as an individual FBS had increased the more individuals have a probability to develop poor treatment outcome.

\section{RECOMMENDATION}

Since the magnitude of treatment outcome were found to be low, the health care providers together with the responsible bodies should strengthen to provide toward improvement of factors affecting the patients by inhibiting them not to be in a state of good treatment.

\section{LIMITATION}

There might be recall bias in the past 7 days while the participants have responding to assess medication adherence.

\section{Conclusion}

According to this study; the magnitude of treatment outcome were found to be low. The study also revealed that dietary practice, presence of complication and having FBS greater than $140 \mathrm{mg} / \mathrm{dl}$ were found to be predicting independently.

\section{Abbreviations}

CBE: Community based education

DM: Diabetes mellitus

HUCSH: Hawassa University Comprehensive Specialized Hospital

WHO: World health organization

\section{Declarations}

\section{Ethics approval and consent to participate}

After the ethical review committee of hawassa University College of medicine and health science have approved; the study was employed. Then after promising confidentiality written informed consent was got from each study participant in order to proceed in the study. An individual who was unenthusiastic to join in the study was allowed to take out. We also assure that there was no danger that put the participant putting the participants at hurt.

\section{Consent for publication}

We all reach to consensus for publication. I am a corresponding author and first author of this finding. 


\section{Consent to publish}

The consent form is held by the authors. Written informed consent was obtained from the participant.

\section{Availability of data and materials}

The study finding were putted in public repositories

\section{Competing interests}

There is no opposing interest.

\section{Funding}

No funding is required. To do this research the researcher did not receive any specific funding and performed as part authors intended to do so by their own intention to do research in the university hospital. It was mainly based on their past experience that we have in the hospital with in the university. Since there is no funder to do this research there is no conflict of interest. We also ask free publication fee since we both authors are living in the developing sub Saharan African country called Ethiopia.

\section{Author's contribution}

The author contributes in conception and design, acquisition of data or analysis and interpretation of data. They also take part in drafting article or revising and approval of the manuscript before it have been published with accountability of the work done in the manuscript

\section{Acknowledgement}

We first acknowledge Ethical review board of Hawassa University College of medicine and health science for running of an ethical clearance. We would also like to acknowledge the Hospitals for providing of agreement for study to be directed in chronic outpatient clinic. Besides; we also like to thank study participants for their valuable contribution in the study.

\section{References}

1. A.S.Fauci,D.L.Kasper,D.L.Longoetal.,Harrison's:Principles of Internal Medicine, McGraw-Hill, New York, NY, USA, 17th edition, 2008.

2. International Diabetes Federation. Diabetes Atlas. IDF. 7th edn. 2015. American Diabetes Association. Standards of Medical Care in diabetes. Diabetes Care. 2015;38(Suppl. 1)

3. World Health organization. Screening for Type 2 Diabetes. 2004;27(Suppl. ) Available from: http://www.who.int/diabetes/publications/en/screening_mnc03.pdf accessed on July 5, 2016.

4. World Health Organization, "Diabetes fact sheet No 312," 2015, http://www.who.int/mediacentre/factsheets/fs312/en. 
5. American Diabetes Association. Standards of Medical Care in diabetes. Diabetes Care. 2015;38(Suppl. (7)

6. M. von Korff, W. Katon, E. H. B. Lin et al., "Potentially modifiable factors associated with disability among people with diabetes," Psychosomatic Medicine, vol. 67, no. 2, pp. 233-240, 2005

7. Litwak L, Goh SY, Hussein Z, Malek R, Prusty V, et al. (2013) Prevalence of diabetes complications in people with type 2 diabetes mellitus and its association with baseline characteristics in the multinational study. Diabetol Metab Syndr 5: 57.

8. Kassahun T,Eshetie T. Gesesew H. Factors associatedwith glycemic control among adult patient with type 2 diabetes mellitius; a cross - sectional study done in Ethiopia. BMC Res Notes.Bio Med Central 2016;9(1);78

9. Fiseha T, Alemayehu E, Kassahun W, Adamu A, Gebreweld A. Factors associated with glycemic control among diabetic adult out-patients in Northeast Ethiopia [Internet]. BioMed Central BMC Res Notes 2018;11(316):4e9, https://doi.org/10.1186/s13104-018-3423-5

10. Alramadan MJ, Afroz A, Hussain SM, et al. Patientrelated determinants of glycaemic control in people with type 2 diabetes in the Gulf Cooperation Council Countries: a systematic review. J Diabetes Res. 2018;2018:9389265.

11. Kayar Y, Ilhan A, Kayar NB, et al. Relationship between the poor glycemic control and risk factors, life style and complications. Biomed Res India. 2017;28(4):1581-6.

12. Gebre BB, Assefa ZM. Magnitude and associated factors of diabetic complication among diabetic patients attending Gurage zone hospitals,South West Ethiopia. BMC Res Notes. 2019;12(1):780. doi:10.1186/s13104-019-4808-9

13. Fasil A, Biadgo B, Abebe M. Glycemic control and diabetes complications among diabetes mellitus patients attending at University of Gondar Hospital, Northwest Ethiopia. Diabetes Metab Syndr Obes. 2019;12:75. doi:10.2147/DMSO.S185614

14. Oluma A, Abadiga M, Mosisa G, Etafa W (2021) Magnitude and predictors of poor glycemic control among patients with diabetes attending public hospitals of Western Ethiopia. PLoS ONE 16(2): e0247634. https://doi.org/10.1371/journal. pone.0247634 